\title{
Some Properties of the Polysaccharide from Cell Cultures Infected with TRIC Agent (Chlamydia trachomatis)
}

\author{
By A. J. GARRETT* \\ $M R C$ Trachoma Unit, The Lister Institute of Preventive Medicine, London $S W \mathrm{I} W 8 R H$
}

(Received 3 March I975)

SUMMARY

The polysaccharide, elaborated in trachoma-inclusion conjunctivitis (TRIC) agent inclusions, was isolated from baby hamster kidney (BHK) cells grown and infected in suspension cultures. It was characterized by physical, chemical and enzymic methods as a glycogen with an average chain length of 14 to I6 glucose units.

\section{INTRODUCTION}

Chlamydiae are obligate intracellular micro-organisms that are classified into two main subgroups, A and B (Gordon \& Quan, 1965). Members of group A, which includes trachoma-inclusion conjunctivitis (TRIC) agents, develop in host cells in well-defined cytoplasmic inclusions that fill with a glucose polymer as infective particles form. Inclusion material stains brown with iodine, is degraded by salivary amylase (Rice, I936) and coprecipitates with shellfish glycogen (Fan \& Jenkin, 1970). It is therefore frequently referred to as glycogen. The difficulties of obtaining sufficient quantities of the polymer for more detailed analyses were overcome by the growth of a TRIC agent in suspended cell cultures (Garrett \& Harrison, 1973), and the structure of the isolated polysaccharide has now been investigated.

\section{METHODS}

TRIC agent. The fast-killing variant (Taverne, Blyth \& Reeve, 1964) of strain TRIC/2/GB/ MRC-4/ON (Jones, 196I) was grown in baby hamster kidney (BHK) cells in suspension (Garrett \& Harrison, 1973).

Enzymes. Amyloglucosidase (Sigma) from Rhizopus sp. was purified by the method of Johnson \& Fusaro (1966). Purified samples of Cytophaga isoamylase and sweet potato $\beta$-amylase were kindly given by Dr J. J. Marshall. Glucose oxidase (Glucostat Regular, Worthington Biochemical Corporation, Freehold, New Jersey, U.S.A.) was reconstituted in $0.5 \mathrm{M}$-tris- $\mathrm{HCl}$ buffer which effectively inhibits possible carbohydrase contaminants but does not interfere with glucose oxidase activity (Dahlqvist, 1964).

Reagents were obtained as follows: shellfish glycogen (Mann Research Laboratories, New York, U.S.A.); rabbit liver glycogen and maltose monohydrate (BDH); bovine plasma albumin (Armour Pharmaceutical Co. Eastbourne); anthrone (BDH) was recrystallized from acetic acid.

Analytical methods. Polysaccharide was measured by the method of Mokrasch (1954) after free glucose had been destroyed, where necessary, by boiling in $5 \mathrm{M}-\mathrm{KOH}$ (van der Vies, 1954); occasionally it was also measured by digestion with amyloglucosidase and

* Present address: National Institute for Biological Standards and Control, Holly Hill, London $\mathrm{NW}_{3} 6 \mathrm{RB}$. 
determination of the glucose released by glucose oxidase (Johnson \& Fusaro, I966). Reducing sugars were measured against a maltose standard by the method of Nelson (1944) modified to give a final volume of $4.6 \mathrm{ml}$. Protein was measured against a bovine plasma albumin standard by the method of Lowry et al. (195I) modified to give a final volume of $\mathrm{I} \cdot \mathrm{I} \mathrm{ml}$.

The reaction of iodine with polysaccharide was studied by adding $0 . \mathrm{I} \mathrm{ml}$ of $0.08 \%$ $(\mathrm{w} / \mathrm{v}) \mathrm{I}_{2}$ in $0.8 \%(\mathrm{w} / \mathrm{v}) \mathrm{KI}$ and $0.2 \mathrm{M}-\mathrm{HCl}$ to $0.3 \mathrm{ml}$ of an aqueous solution containing about $150 \mathrm{mg}$ polysaccharide. The absorbance of the iodine-polysaccharide complex was read at $490 \mathrm{~nm}$.

Acid hydrolysis of polysaccharide. Samples were hydrolysed with $\mathrm{I} M-\mathrm{H}_{2} \mathrm{SO}_{4}$ or $2 \mathrm{M}-\mathrm{HCl}$ in sealed tubes at $100{ }^{\circ} \mathrm{C}$ for $2 \mathrm{~h}$. The $\mathrm{H}_{2} \mathrm{SO}_{4}$ was neutralized with $\mathrm{BaCO}_{3}$; the $\mathrm{HCl}$ was removed by evaporating in vacuo over $\mathrm{CaCl}_{2}$ and $\mathrm{NaOH}$.

Thin-layer and paper chromatography of hydrolysates and digests was done on precoated cellulose plates (Merck) and Whatman No. 4 paper in $n$-butanol-pyridine-water (6:4:3, by vol.) (Jeanes, Wise \& Dimler, 195I). Carbohydrates were detected with $\mathrm{AgNO}_{3}-$ $\mathrm{NaOH}$ (Partridge, I948); background colour was bleached with $20 \%$ (w/v) $\mathrm{Na}_{2} \mathrm{~S}_{2} \mathrm{O}_{3} \cdot{ }_{5} \mathrm{H}_{2} \mathrm{O}$.

Infrared spectrometry. Freeze-dried samples were analysed in a Perkin-Elmer spectrometer.

Isolation of polysaccharide. The polysaccharide associated with TRIC-infected BHK cells is degraded enzymically by cell homogenates at neutral or slightly acid pH (Evans, 1972; Garrett \& Harrison, 1973). To avoid this, cells infected $48 \mathrm{~h}$ earlier were therefore harvested by centrifugation at $600 \mathrm{~g}$ for $10 \mathrm{~min}$ and extracted with $5 \%(\mathrm{w} / \mathrm{v})$ trichloroacetic acid (TCA) for $\mathrm{I} \mathrm{h}$ at $0^{\circ} \mathrm{C}$; preliminary experiments showed that TCA extracted all the polysaccharide from infected cells. The suspension was centrifuged at $600 \mathrm{~g}$ for $\mathrm{I} 0 \mathrm{~min}$, the precipitate washed twice with $5 \%(\mathrm{w} / \mathrm{v}) \mathrm{TCA}$, and the extract and washings were combined and dialysed against distilled water. The non-diffusible fraction was adjusted to $\mathrm{pH} 8$ with $\mathrm{NaOH}$ and concentrated by freeze-drying. Some purification of this material was achieved by passage through an Amberlite MB-6 resin $(22 \times \mathrm{I} \cdot 5 \mathrm{~cm})$ at $4{ }^{\circ} \mathrm{C}$, and the polysaccharide was recovered in the void volume as an opalescent solution; samples of each fraction were analysed for polysaccharide by the method of Mokrasch (1954).

Determination of average chain lengths of polysaccharide. The average unit chain length $(\overline{\mathrm{CL}})$ and the average outer chain length $(\overline{\mathrm{OCL}})$ were determined by the method of GunjaSmith, Marshall \& Smith (197I) which is based on the enzymic degradation of branched $\alpha-I, 4$ and $\alpha-I, 6$ glucose polymers. Isoamylase hydrolyses $\alpha-I, 6$ bonds and liberates unbranched chains with reducing sugar ends; $\beta$-amylase hydrolyses alternate $\alpha-1,4$ bonds of unbranched chains and leaves stubs of maltose and maltotriose at branch points (Fig. I). Polysaccharide $(0.5$ to $\mathrm{I} \mathrm{mg} / \mathrm{ml})$ in $20 \mathrm{~mm}$-sodium acetate-acetic acid, $\mathrm{pH} 5.5$, was incubated with Cytophaga isoamylase $(0.06$ units $/ \mathrm{ml})$ at $37^{\circ} \mathrm{C}$. The degree of $\beta$-amylolysis was determined by digestion of polysaccharide $(0.25$ to $0.5 \mathrm{mg} / \mathrm{ml})$ with $\beta$-amylase (30 units $/ \mathrm{ml})$ in Io mM-sodium acetate-acetic acid buffer, $\mathrm{pH} 4 \cdot 8$. Duplicate samples from both digests were taken at intervals, inactivated by heating at $100{ }^{\circ} \mathrm{C}$ for $20 \mathrm{~min}$ and analysed for reducing sugar. Average chain lengths (expressed in glucose units) were calculated from the formulae:

Average chain length $(\overline{\mathrm{CL}})=\frac{2 \times \text { total polysaccharide in digest (maltose equiv.) }}{\text { Reducing sugar released (maltose equiv.) }}$

Average outer chain length $(\overline{\mathrm{OCL}})=\overline{\mathrm{CL}} \times(\% \beta$-amylolysis $)+2 \cdot 5$

Average interior chain length $(\overline{\mathrm{ICL}})=\overline{\mathrm{CL}}-\overline{\mathrm{OCL}}-\mathrm{I}$. 


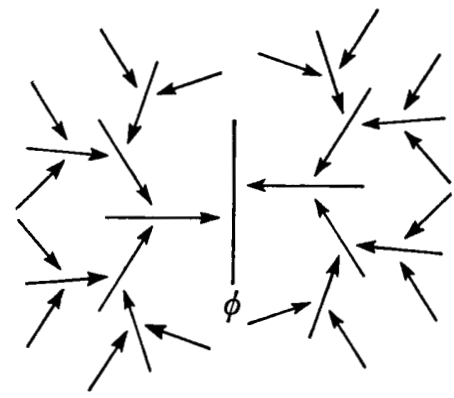

Fig. I. Glycogen structure proposed by Gunja-Smith et al. (1970). $\phi$, Reducingend group; $-,-\alpha-1,4$ glucan chains; $\longrightarrow /,-\alpha-\mathrm{I}, 6$ glycoside branch points.

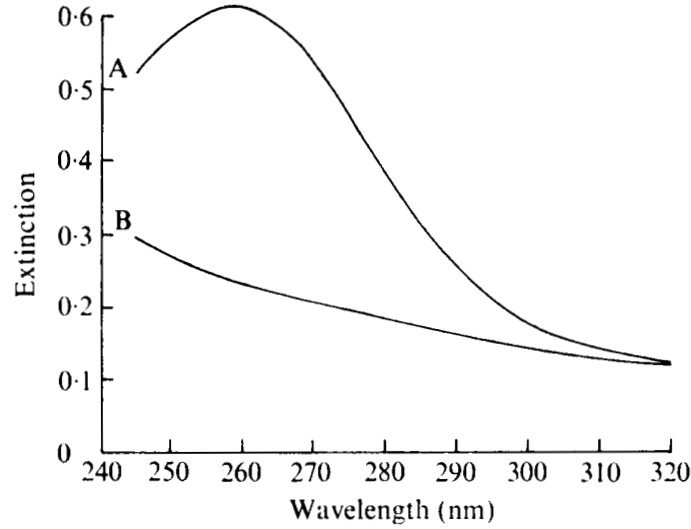

Fig. 2.

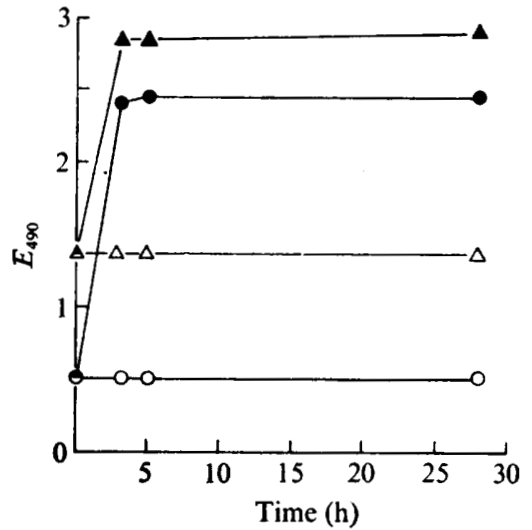

Fig. 3.

Fig. 2. Ultraviolet spectrum of polysaccharide from TRIC agent before (A) and after (B) passage through Amberlite MB-6 resin. The concentration of the preparation used in B was 20 times that used in A.

Fig. 3. Effects of enzymic degradation of polysaccharides on iodine adsorption. $\triangle$, TRIC agent polysaccharide control; $\Delta$, TRIC agent polysaccharide+isoamylase; $O$, shellfish glycogen control; $\bullet$, shellfish glycogen + isoamylase.

\section{RESULTS}

A I 1 culture containing $10^{9}$ infected BHK cells yielded about $20 \mathrm{mg}$ polysaccharide (expressed as glucose equivalents). Passage of the extract through a column of Amberlite MB-6 resin reduced $260 \mathrm{~nm}$-absorbing contaminants to negligible amounts (Fig." 2 ) and the protein content from $10 \%$ to $\mathrm{I} \cdot 5 \%$ of the glucose content; at least $95 \%$ of the polysaccharide applied to the column was recovered in the void volume.

Chemical composition. Glucose was the only sugar detectable by thin-layer and paper chromatography of acid hydrolysates of the polysaccharide. However, measurements of sugar by the anthrone reaction and by sequential digestion with amyloglucosidase and glucose oxidase showed that $5 \%$ of the polymer was either another sugar or composed of glucose groups bound differently from that in a glycogen.

Measurement of average chain lengths. Separate samples of polysaccharide were degraded with isoamylase, with $\beta$-amylase, or with isoamylase followed by $\beta$-amylase. Average chain 
Table I. Chain lengths of TRIC agent polysaccharide

\begin{tabular}{|c|c|c|c|c|c|}
\hline & \multirow[b]{2}{*}{$\overline{\mathrm{CL}}$} & \multirow[b]{2}{*}{$\overline{\mathrm{OCL}}$} & \multirow[b]{2}{*}{$\overline{\mathrm{ICL}}$} & \multicolumn{2}{|c|}{$\beta$-Amylolysis (\%) } \\
\hline & & & & $\begin{array}{c}\text { Before } \\
\text { debranching }\end{array}$ & $\begin{array}{c}\text { After } \\
\text { debranching }\end{array}$ \\
\hline $\begin{array}{l}\text { TRIC agent polysaccharide } \\
\text { Shellfish glycogen }\end{array}$ & $14-16$ & I I-I 2 & $2-3$ & 60 & 95 \\
\hline (This study) & 12 & 7 & 3 & 38 & 95 \\
\hline (Gunja-Smith et al. 197I) & I0 & 6 & 3 & 39 & IOI \\
\hline (Walker \& Whelan, 1960) & II & 7 & 2 & 39 & ND \\
\hline
\end{tabular}

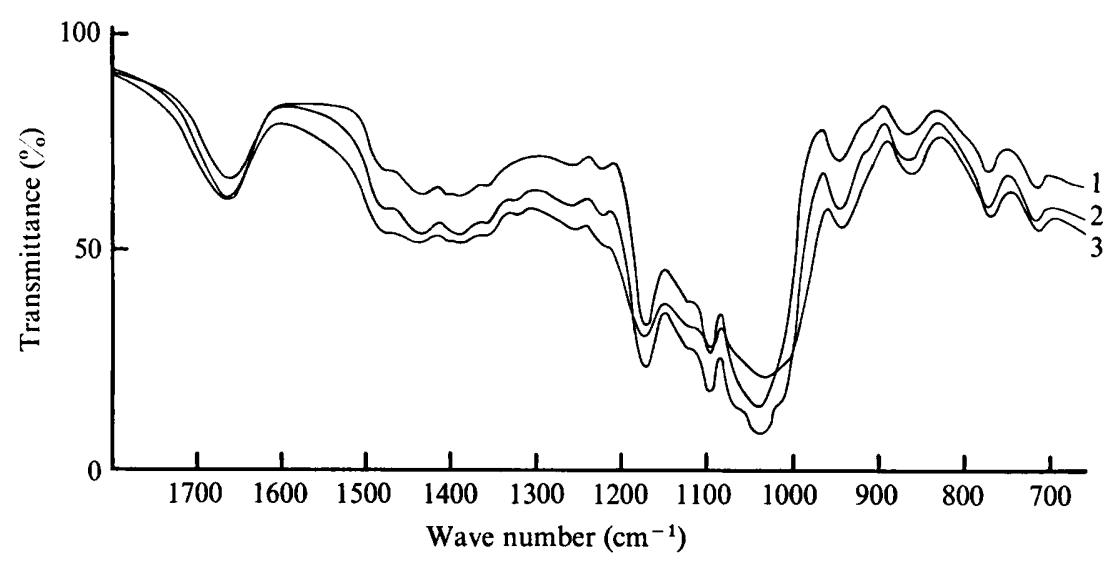

Fig. 4. Infrared spectra of TRIC agent polysaccharide (I), shellish glycogen (2), and rabbit liver glycogen (3).

lengths were calculated from the amounts of reducing sugar released after completion of these digestions (Table r). Complete digestion of the polysaccharide with isoamylase and then $\beta$-amylase revealed glucose, maltose and a very small amount of material that reduced $\mathrm{AgNO}_{3}$ and ran on thin-layer chromatograms with an $R_{\text {maltose }}$ of 0.69 .

Reaction with iodine. Further information on the nature of the polysaccharide was obtained by examining the complex formed with $\mathrm{I}_{2}-\mathrm{KI}$ in the presence and absence of $\left(\mathrm{NH}_{4}\right)_{2} \mathrm{SO}_{4}$. The addition of an equal volume of saturated $\left(\mathrm{NH}_{4}\right)_{2} \mathrm{SO}_{4}$ increased the extinction of the complex twofold and altered the $\lambda_{\max }$ from 465 to $505 \mathrm{~nm}$. These reactions are typical for glycogens, and an approximate value of $16 \pm 2$ for $\overline{\mathrm{CL}}$ is derived from $\lambda$ in $50 \%$ saturated $\left(\mathrm{NH}_{4}\right)_{2} \mathrm{SO}_{4}$ and the formula $\overline{\mathrm{CL}}=16 \pm 0.114\left(\lambda_{\max }=500\right)$ (Archibald et al. I96I).

Debranching enzymes, such as isoamylase, hydrolyse $\alpha-\mathrm{I}, 6$ bonds and convert highly branched glucans to a mixture of straight chain glucans which may then be complexed with $\mathrm{I}_{2}-\mathrm{KI}$. Isoamylase treatment increased the iodine-staining powers of shellfish glycogen and polysaccharide from TRIC-infected cells (Fig. 3).

Infrared spectrometry. The infrared spectrum of TRIC agent polysaccharide was identical with that of glycogen from shellfish or from rabbit liver (Fig. 4). 


\section{DISCUSSION}

Polysaccharide from inclusions formed by a TRIC agent was separated from BHK host cells and from the chlamydiae that induced its formation, and the results presented here substantiate the long-held belief that it is a glycogen. Production of a brown complex with iodine is not, by itself, sufficient evidence to identify the inclusion material as a glycogen; other polysaccharides and protein also stain weakly with iodine. However, the large changes in absorbance and $\lambda_{\max }$ that accompanied the addition of $\left(\mathrm{NH}_{4}\right)_{2} \mathrm{SO}_{4}$ to polysaccharideiodine mixtures are characteristic of glycogens, and, most important, highly purified and specific enzyme preparations of isoamylase and $\beta$-amylase (Gunja-Smith et al. 1971; Mercier, Frantz \& Whelan, 1972) digested the polymer almost completely. The average chain length ( $16 \pm 2$ glucose units) calculated from the $\lambda_{\max }$ of the iodine complex agrees well with that ( 14 to 16 ) from the much more reliable enzymic method. The increase in iodine-staining power that accompanied digestion of the polysaccharide with isoamylase (Fig. 3) confirmed that the polymer was an $\alpha-I, 4$ glucan joined by $\alpha-I, 6$ branch points. The small residue of polysaccharide resistant to enzyme action may be a core in which glucose is held by bonds other than $\alpha-\mathrm{I}, 4$ and $\alpha-\mathrm{I}, 6$. The $\beta$-amylolysis limit, the average chain lengths and the infrared spectrum are all similar to the values reported for other glycogens.

Recent findings suggest that chlamydiae produce an enzyme (or enzymes) that directs polysaccharide synthesis, although the host cell controls the amount of polymer formed in the inclusion (Jenkin \& Fan, I97I; Evans, 1972).

Although the function of the glycogen is still unknown, the fact that it is elaborated late in the growth cycle (Reeve \& Taverne, 1967) and deposited outside the elementary bodies makes it unlikely that it serves as an energy reserve similar to the storage glycogens of some other bacteria. Under certain conditions the polysaccharide is so closely associated with elementary bodies as to resemble a capsule, and inclusion material containing elementary bodies and retaining the shape and staining characteristics of the original inclusion has been isolated free from host cells (Blyth, Taverne \& Garrett, I97I). Similar aggregates have also been observed in TRIC-infected yolk sacs (Sowa \& Collier, I960). The polysaccharide may therefore be a structural component involved in some way with the development or release of infective particles. Its presence must alter the osmotic pressure within the inclusion, and could thus affect transport of nutrients or metabolites through the inclusion membrane.

Enzyme deficiencies in certain glycogen storage diseases lead to the production of various abnormal liver glycogens (Manners, I962; Edstrom, I972), some of which resemble amylopectins more closely than glycogens. It is tempting, therefore, to speculate that trimethoprim, which inhibits TRIC elementary body formation (Reeve, Taverne \& Bushby, I968) and which can induce the formation of inclusions that stain blue or black with iodine (P. Reeve and J. Taverne, unpublished observations), may alter the normal synthesis of polysaccharide by inhibiting branching enzymes. Trimethoprim at ten times the median inhibitory concentration for TRIC agent is required to elicit toxic effects in host cells (Reeve et al. I968), and examination of the structures of polysaccharides formed in the presence of antibacterial drugs may identify the role played by TRIC agent in polysaccharide synthesis.

The polysaccharide may have some serological activity; non-particulate matter in inclusions stains with fluorescent antibody against TRIC antigen (A. E. Mogg, unpublished observations), and rabbit antisera prepared against crude polysaccharide extracts of TRIC-infected BHK cells neutralize TRIC agent infectivity (A. Evans, unpublished 
observations). However, the role of polysaccharide in these reactions has not been established.

I am grateful to Miss Nicci Yianni for skilled technical assistance, and to Dr E. A. Johnson of the National Institute for Biological Standards and Control for the infrared analyses.

\section{REFERENCES}

Archibald, A. R., Fleming, I. D., Liddle, A. M., Manners, D. J., Mercer, G. A. \& Wright, A. (196I). $\alpha-\mathrm{I}, 4$ Glucosans. XI. The absorption spectra of glycogen- and amylopectin-iodine complexes. Journal of the Chemical Society, I183-I190.

Blyth, W. A., TAVERnE, J. \& GARRETT, A. J. (1971). Trachoma inclusions separated from cells. In Trachoma and Related Disorders, pp. 79-87. Edited by R. L. Nichols. Amsterdam: Excerpta Medica.

DAHLQVIST, A. (1964). Method for assay of intestinal disaccharidases. Analytical Biochemistry 7, 18-25.

EDSTROM, R. D. (1972). Structure of a low molecular weight form of glycogen isolated from the liver in a case of glycogen storage disease. Journal of Biological Chemistry 247, I360-1367.

Evans, A. (1972). The development of TRIC organisms in cell cultures during multiple infection. Journal of Hygiene 70, 39-48.

FAN, V. S. C. \& JENKIN, H. M. (1970). Glycogen metabolism in chlamydia-infected HeLa cells. Journal of Bacteriology 104, 608-609.

GARRETT, A. J. \& HARRISON, M. J. (1973). The development of a TRIC agent (Chlamydia trachomatis) and its associated polysaccharide in suspended cell cultures. Journal of General Microbiology 78, 297-303.

Gordon, F. B. \& QUAN, A. L. (1965). Occurrence of glycogen in inclusions of the psittacosis-lymphogranuloma venereum-trachoma agents. Journal of Infectious Diseases II6, I86-196.

Gunja-Smith, Z., Marshall, J. J., Mercier, C., Smith, E. E. \& Whelan, W. J. (I970). A revision of the Meyer-Bernfeld model of glycogen and amylopectin. FEBS Letters 12, 10I-104.

Gunja-Smith, Z., Marshall, J. J. \& Smith, E. E. (I97I). Enzymatic determination of the unit chain length of glycogen and related polysaccharides. FEBS Letters 13, 309-3I I.

JeANes, A., Wise, C. S. R. \& DimleR, R. J. (I95I). Improved techniques in paper chromatography of carbohydrates. Analytical Chemistry 23, 415-420.

Jenkin, H. M. \& FAN, V. S. C. (I97I). Contrast of glycogenesis of Chlamydia trachomatis and Chlamydia psittaci strains in HeLa cells. In Trachoma and Related Disorders, pp. 52-59. Edited by R. L. Nichols. Amsterdam: Excerpta Medica.

Johnson, J. A. \& FusARo, R. M. (1966). The quantitative enzymic determination of animal liver glycogen. Analytical Biochemistry 15, 140-149.

JoNES, B. R. (I96I). TRIC virus infections in London. Transactions of the Ophthalmological Society of the United Kingdom 8r, 367-378.

Lowry, O. H., Rosebrough, N. J., Farr, A. L. \& Randall, R. J. (I95I). Protein measurement with the Folin phenol reagent. Journal of Biological Chemistry 193, 265-275.

ManNers, D. J. (1962). Enzymic synthesis and degradation of starch and glycogen. Advances in Carbohydrate Chemistry 17, 37I-430.

Mercier, C., Frantz, B. M. \& Whelan, W. J. (1972). An improved purification of cell-bound pullulanase from Aerobacter aerogenes. European Journal of Biochemistry 26, I-9.

MoKraSCH, L. C. (1954). Analysis of hexose phosphates and sugar mixtures with the anthrone reagent. Journal of Biological Chemistry 208, 55-59.

Nelson, N. (1944). A photometric adaptation of the Somogyi method for the determination of glucose. Journal of Biological Chemistry 153, 375-380.

PARTRIDGE, S. M. (1948). Filter paper partition chromatography of sugars. Biochemical Journal 42, 238-248.

REEVE, P. \& TAVERNE, J. (1967). Strain differences in the behaviour of TRIC agents in cell cultures. American Journal of Ophthalmology 63, I167-1173.

ReEVE, P., TAVERNE, J. \& BUSHBY, S. R. M. (I968). Inhibition by pyrimidine analogues of the synthesis of folic acid by trachoma agents. Journal of Hygiene 66, 295-306.

RICE, C. E. (1936). The carbohydrate matrix of the epithelial-cell inclusion in trachoma. American Journal of Ophthalmology 19, I-8.

SowA, J. \& Collier, L. H. (1960). Isolation of trachoma virus from patients in West Africa. Journal of Hygiene 58, 99-108. 
TAVerne, J., Blyth, W. A. \& Reeve, P. (1964). Toxicity of the agents of trachoma and inclusion conjunctivitis. Journal of General Microbiology 37, 271-275.

VAN DER VIES, J. (1954). Two methods for the determination of glycogen in liver. Biochemical Journal 57, 4IO-4I6.

WALKER, G. J. \& Whelan, W. J. (1960). The mechanism of carbohydrase action. 8. Structures of the muscle-phosphorylase limit dextrins of glycogen and amylopectin. Biochemical Journal 76, 264-268. 